\title{
Az informatika batása a big data korszakban a román könyvvizsgálók megítélése alapján
}

ÖsszzFoglaló: Mint minden üzleti folyamat, így a könyvvizsgálat is tökéletesíthető, mivel a fejlett adatfeldolgozási készségeket kiegészíti a technológia. A jelen cikkben a román könyvvizsgálók munkamódszereit vizsgáljuk, valamint azt, hogy szerintük milyen hatást gyakorol az informatika a könyvvizsgálói megbízások végrehajtására. A 102 résztvevővel végzett felmérés válaszai között többször előfordultak bizonyos módszerek és eszközök (adatelemzés, Microsoft Excel, adatautomatizálás), amelyek a big data elemzésével megkönnyítik a könyvvizsgálati folyamatot. A használatra kész, feltörekvő technológiák közül a leggyakrabban a Ciel Audit and Revision, a Gaudit és a CaseWare szoftvereket használják a könyvvizsgálók. Az új technológiákról szóló szakmai ismeretek folyamatos bővitését szakmai továbbképzések és áttogó dokumentációk biztosítják. Romániában az új technológiák alapján jelenleg átlagos szinten végeznek könyvvizsgálatokat, a jövőben magasabb szint, magasabb előrejelzési és elemzési kapacitás várható. A könyvvizsgálói szakmát egyre inkább tökéletesítik, a munkafolyamatba fokozatosan beépítik az új technológiákat. A külső környezet is jobban megbecsüli a könyvvizsgálókat, akik alapvetően továbbra is szakmai szkepticizmussal, valamint a versenykörnyezet ismeretével jellemezhetók. Bizonytalanság övezi a Nemzetközi Könyvvizsgálati Standardok (ISA) módosítását. A jelen cikk azáltal gazdagítja a szakirodalmat, hogy a könyvvizsgálói szakma jelenlegi technológiai környezetét helyezi előtérbe, nevezetesen a negyedik ipari forradalom során a könyvvizsgálók által észlelt hatásokat.

KuLcsszavak: könyvvizsgálók észrevételei, informatika hatása, adatelemzés, könyvvizsgálói megbizás

JEL-KóD0K: M40, M42

DOl: https://doi.org/10.35551/PSZ_2021_k_1_4

Romániában a pénzügyi könyvvizsgálói szakma a szabályozás és a digitalizáció metszetében helyezkedik el, mivel a 21 . századot a szabályozás reformja, valamint az üzleti környezet és a technológia szoros kapcsolata jellemzi. A világ minden táján minden ágazat részt vesz a negyedik ipari forradalomban, ez az átalakulás

Levelezési e-cim: cristealaviniamihaela@yahoo.com munkahelyek millióit szünteti meg, ugyanakkor új munkahelyeket teremt a fiatalok számára, akik most tanulmányaik korai szakaszában vannak. E forradalom miatt a külső környezetnek (azaz a munkavállalóknak és a munkaadóknak) továbbképzési programokat kell szerveznie, figyelemmel kell kísérnie a feltörekvő technológiákat, valamint kritikus szemmel kell követnie, hogy az alkalmazkodás és az 
újításra való ösztönzés sikerrel jár-e, mivel a technológia minden tevékenységi területen teret kap (például kommunikáció, közigazgatás, kutatás, fejlesztés, innováció, pénzügyi ágazat). A jelen cikkben a könyvvizsgálói szektort kutatjuk, és megvizsgáljuk az új technológiák hatásait a szakmára nézve, amihez elemezzük a román könyvvizsgálók észrevételeit a big data korszakában.

A hagyományos könyvvizsgálat olyan könyvvizsgálói gyakorlaton alapszik, amelynél a pénzügyi adatok megfigyelése, ellenőrzése és elemzése emberi szakértelem segítségével történik (Byrnes et al., 2018). Az említett folyamatok képviselik a fö megközelítést a könyvvizsgálat területén, beleértve a pénzügyi ellenőrzést is (Gepp, 2018). A pénzügyi ellenőrzés olyan összetett folyamat, amelyet gyakran manuálisan, az eljárások szintjén végeznek. Idővel a számítógéppel támogatott könyvvizsgálati technikák (Computer Assisted Audit Techniques - CAAT) is beavatkoztak e folyamat támogatásába, és ellátták az ismétlődo” munkafeladatokat. A CAAT-ok a könyvelési folyamatot elősegítő, elektronikus alátámasztó számviteli okmányok (például számlák, átvételi elismervények és eltérések megállapítása, számviteli nyilvántartások) gyors ellenőrzését biztosítják. E munkatechnikák a könyvvizsgálói megbízás bármely szakaszában alkalmazhatók, a könyvvizsgálói jelentés tervezésétől kezdve, az ügyfélről szóló ismeretek gyűjtésén és a részletes tesztek végrehajtásán keresztül, egészen a belső kontrollok értékeléséig és az adatok sértetlenségének ellenőrzéséig.

Jelenleg a pénzügyi ellenőrzési megbízásokat továbbra is CAAT-okkal, tehát a könyvvizsgálók által az ellenőrzési folyamat javítására alkalmazott, különféle szoftverekkel hajtják végre. A könyvvizsgálók által leggyakrabban alkalmazott eszközök a Microsoft Excel, az ACL és az Access adatbázisok, a SAS segítségével végzett statisztikai elemzés és a CaseWare IDEA. Ezek a munkaeszközök olyan tevékeny- ségekhez szükségesek, mint például az ügyféladatok vizsgálata, a részletes elemzésekhez és a komplex vizsgálatokhoz szükséges megfelelő pénzügyi előkészítés végrehajtása, vagy akár az információk gyorsabb kinyerése (Gray, Debreceny, 2014; Caranica, 2016; Moffitt et al., 2018; Cohen, Rozario, 2019; Gartner, 2019). E tevékenységek jellemzően olyan munkafeladatokat tartalmaznak, amelyeknél több millió számviteli tételből kell kiszűrni a jelenleg nem használt tételeket, például - a román számlatükör szerinti - 462-es „Egyéb kötelezettségek” számla, 151-es „Céltartalékok” számla, 4118-as „Rendezetlen tételek” számla, 781-es „Céltartalékokból származó bevétel” számla. A szürők beállítása olyan hasonló helyzeteken alapszik, amelyeket a könyvvizsgáló korábban nem megfelelőnek vagy potenciális csalási kockázatnak talált.

A jelen cikkben azt vizsgájuk, hogy a bejegyzett román könyvvizsgálók milyen mértékben használják az új technológiákat, milyennek látják a technológia kezdeti hatásait és hogyan alkalmazkodnak, végül pedig hogy szükség lesz-e a pénzügyi beszámolási standardok megváltoztatására e szakma digitalizációjának kiteljesítéséhez. E cikkben az „új”, „feltörekvo"” és „kognitív” (technológia) kifejezéseket azonos értelemben használjuk.

\section{A SZAKIRODALOM ELEMZÉSE}

A közelmúltban jelentősen nőtt a technológiába folyamatosan befektető nagyvállalatok száma, a kognitív technológiák forradalmasították a könyvvizsgálatot és a pénzügyi beszámolást. A könyvvizsgálók számára a kognitív technológiák szélesebb képet biztosítanak a pénzügyi folyamatokról, hiszen vizuálisan mutatják be az üzleti stratégiákat és modelleket, valamint a továbbtökéletesíthető üzleti folyamatokat. A kognitív technológiák javítják a könyvvizsgálati folyamatokat és az el- 
végzett könyvvizsgálói megbízás minőségét, mivel segítik elemezni és megérteni, hogy a vállalat milyen kockázatokkal szembesül, tehát ahol a kontroll hiányosságokat mutat. Ily módon a könyvvizsgálók képesek a szervezet gyengeségeire (azaz a kockázatos szektorokra) összpontosítani, mivel a big data vizsgálat következő (alaposabb) fokozatát végzik el adatelemzési eszközök, gépi tanulás (Machine Learning - ML), robotizált folyamatautomatizálás (Robotics Process Automation - RPA), a blokklánc (blockchain) technológia és mesterséges intelligencia (Artificial Intelligence - AI) alkalmazásával.

A kognitív technológiák alkalmazásával a könyvvizsgálói szektor maradandóan megváltozik (KPMG, 2017). Azok a könyvvizsgálói szolgáltatásokat kínáló vállalatok, amelyek nem fektetnek be új technológiai megoldásokba, azt kockáztatják, hogy elmaradnak azon versenytársaiktól (például IBM, Microsoft), akik már alkalmazzák ezeket a technológiákat. Az új technológiai módszerek felhasználói fejlödést tapasztalnak a belső kontroll monitorozása (tehát a feladatok szétválasztása, a megfelelő kockázatkezelési és kontrollstratégiák, vállalati teljesítmények nyomon követésének folyamatai, időszakos értékelések) tekintetében. Az új technológiai módszer (belső kontroll-monitorozása) segít meghatározni a hiányosságok fó okait és következményeit. A kognitív technológiák irányába tett fejlődés átalakítja a könyvvizsgálói megbízásokat, kezdve a munkában használt eljárásoktól a hozzáadott értéket képviselő ellenőrzésig. A kognitív technológiákkal azoknak a statisztikai technikáknak a megértésére is utalunk, amelyek elősegítik az emberi nyelv elemzését, megértését és előállítását, mivel a gépi tanulás biztosítja a felhasználó és a rendszer közötti felületet írásban és hangban egyaránt, átalakítva és a gép által érthetővé téve a természetes nyelvet.

Ha a régi munkamódszereket összehasonlítjuk a jelenlegiekkel, akkor jelentős javulás fi- gyelhető meg a valós idejü adatokkal kapcsolatos eredményekben (Cangemi, 2015; Castka et al., 2020), ami a munkának és a könyvvizsgálói pozícióból felügyelt kognitív technológiáknak köszönhető. A KPMG (2017) bízik a „felügyelt kognitív” technológiákban, ugyanis ez a kognitív tudomány és a hivatásos könyvvizsgálók tudásának és készségeinek ötvözete, ezáltal a könyvvizsgálói megbízások teljesítésének legjobb módja. A kognitív technológiák lehetővé teszik az elemzések vezetését, az értékes információk feltárását és a szakmai megítélés kialakítását.

A KPMG (2017) véleménye szerint azért szükséges az RPA, ML és AI kognitív technológiákba beruházni, mert a könyvvizsgáló cég az intelligens ellenőrzésen keresztül tudja üzleti célkitűzéseinek folytonosságát és könyvvizsgálói megbízásainak jó minőségét biztosítani (Vasarhelyi, 2020). A neurolingvisztikus programozás ismerete (Neuro Linguistic Programming - NLP) hozzájárul olyan intelligens alkalmazásformák megismeréséhez, mint például a chatbotok (azaz csevegőrobotok) vagy az intelligens ügynökök, amelyek támogatást nyújtanak a digitális világban. Az NLP és az ML ismerete segítheti a könyvvizsgálókat a döntéshozatali folyamatokban, mert korábbi könyvvizsgálói megbízásokból átültetett sémákat azonosíthatnak, vagy pontosabb előrejelzéseket készíthetnek a csalás kockázatáról és a számviteli tranzakciók gyanúsnak tekinthető kezeléséről. A technológia tehát a könyvvizsgáló munkamódszerét támogatja és egészíti ki, és nem a szakember helyébe lép (Castka et al., 2020). Az informatika „szándéka” az emberi kapacitás felerősítése, és nem lemásolása (Deloitte, 2018).

Köztudott, hogy a jelenlegi gazdasági helyzetet a gazdaság lassúsága és nagyfokú bizonytalanság jellemzi, és emellett zajlik a szabályozási folyamat is. A digitális átalakítások miatt a könyvvizsgálók nehezen értelmezik a big data jelenséget, ezek az adatok ugyanis különböző 
formátumúak. A könyvvizsgálók ezért olyan analitikai eszközöket használnak, amelyek biztosítják az ügyfelek adatainak heterogenitását (Moffitt et al., 2018; Cohen, Rozario, 2019; Vasarhelyi, 2020), hiszen a könyvvizsgálók szakértői szerepet töltenek be a könyvvizsgálói megbízás összehangolásában és a végső következtetések megfogalmazásban (Castka et al., 2020). Romániában a könyvvizsgálók leginkább a Microsoft Excel, a Ciel Audit and Revision, a CaseWare és a Gaudit rendszereket használják. Az említett szoftvereknek sok erőssége van, például az egyszerű adatfelhasználás, gyors információelérés, költségcsökkentés, többféle adatkezelési lehetőség (Caranica, 2016). A könyvvizsgálói megbízásokhoz használt szoftveralkalmazásokhoz hasonlóan a Microsoft Excel és a CaseWare is megkönynyíti a könyvvizsgálati teszteket. Ezeket gyakran használják azok a könyvvizsgálók, akik még nem ismerik a feltörekvő technológiákat (Laureano, Pedrosa, 2016; William, Prawitt, 2016; Leite, Silva, 2018; Moffitt et al., 2018; Anders, 2019; Cohen, Rozario, 2019).

A nagy könyvvizsgáló cégek (tehát a Big Four) már felismerik, támogatják, tesztelik és alkalmazzák is a feltörekvő technológiákat. Az új technológiák támogathatják a könyvvizsgálói megbízás minőségét, különösen a forgalmas időszakokban, amikor a könyvvizsgálók esetleg nagyon sok megbízással szembesülnek. Ebben a tekintetben a közelmúlt tudományos munkái felismerik az informatika hatását, amellyel hozzájárul a pénzügyi ellenőrzés folyamatának javításához (Zhang et al., 2015). Ennek kialakulását támogatja a big data jelenség (Griffin, Wright, 2015; Brown-Liburd, Vasarhelyi, 2015), a blokklánc-technológia (Sutton, 2017; Ahmad, 2018; Rozario, 2019; Vasarhelyi, 2020), a gépi tanulás és az RPA (Clark, 2018; Tiwari, 2018; Castka et al., 2020; Vasarhelyi, 2020). Az RPA automatizálhatja azt a munkamennyiséget, amely egységes formátumfeldolgozásból áll és rutinsze- rü folyamatot követel (például a számlák és a megfelelő kifizetések egyeztetésének folyamata a szerződés számának vagy az ügyfél nevének azonosításával). Az RPA olyan automatizáló eszközöket tartalmaz, amelyek jól ismert folyamatokat követnek, például a felhasználó által egyszer elvégzett tesztelési műveletek halmazát megismétlik, és így az ellenőrzést kézi beavatkozás nélkül elvégzik (Vasarhelyi, 2020).

Jelenleg a hagyományos könyvvizsgálatról a folyamatos/techikai/jövőbeli auditra való áttérést a szakirodalom olyan fejlődési szakaszként (Byrnes et al. 2018), olyan digitális világba vezető utazásként mutatja be, amely (a jövőre nézve) több erőfeszítést igényel a szakemberek részéről (CPA, 2017). Erre a fejlesztésre a könyvvizsgálók által nem könnyen elvégezhető, specifikus és szűkített ellenőrzési eljárásra, illetve komplex ellenőrzési munkaterhelések automatizálására van szükség. Komplex ellenőrzési munkaterhelések alatt olyan tevékenységeket értünk, amelyek több forrásból származó, különböző formátumú, részletes feldolgozást igénylő, nem rutinszerű folyamatokat tartalmaznak. Az automatizálás okozta változások a dokumentumok feldolgozására is vonatkoznak. Ebben a lépésben a könyvvizsgálók ellenőrzik az ugyanazon szállító által kiállított számlákat, előfordulhat áfafeltüntetés-nélküli külső számla, többsoros számla, esedékességnélküli többoldalas számla (szerződés vagy kapcsolódó megrendelés szerint), pénznem megadása nélküli számla vagy csaknem azonos számlaszám (csak egy rövid utótaggal kiegészítve). Az összes említett példa esetében összetett ellenőrzési eljárás szükséges.

$\mathrm{Az}$ adatfeldolgozás és az üzleti problémák azonosítása után a könyvvizsgáló elemezheti az összetett üzleti folyamatokat, és megtalálhatja az okokat (például késedelmes fizetéshez kapcsolódó szerződés, olyan ügyfelek, akik nem teljesítik időben a szerződéses kötelezettségeket) és a problémákat (például hibás szállítási folyamat, rosszul megszövegezett záradékok). 
Ebben a tekintetben bármilyen üzleti folyamatot szét lehet bontani egységesített üzleti folyamatokká, majd ezt követi a sémák létrehozása. A sémák tartalmazhatnak készletlistákat, megrendeléseket, számlákat és fizetési ellenőrzéseket. A lebontás után a munkafolyamatok az adatelemzési eszközök és a gépi tanulási technika segítségével elemezhetők.

$\mathrm{Az}$ adatelemzési eszközök segítségével a könyvvizsgálók könnyen kiértékelhetik az információkat a nagy mennyiségű adatból (Big Data) a pénzügyi adatok értelmezése és az ezekből levonható következtetések megfogalmazása érdekében. Az adatelemzési technikák figyelembevételével az emberi érvelések, amelyek bizonyos esetekben korlátozottak lehetnek, legyőzhetővé válnak. Valójában ez az adatelemzés egyik fö előnye: olyan összetett és rejtett változókat tár fel, amelyeket az emberi tényező nem tudott azonosítani az adott pillanatban, ezáltal az adatelemzés csökkenti az intuíció kényszerű használatát, és tényekkel támasztja alá a hipotéziseket. A tranzakciók mögött meghúzódó valóságot átvilágítási folyamattal lehet kinyerni, kiemelve az ellenőrzött szervezet számára a jelentős lehetőségeket (ami a munka eredménye, a kimenet).

A fejlett, dinamikus, integrált analitikai eszközök használatával a román könyvvizsgálók jelentősen részletezett információkhoz juthatnak. Az adatelemzés e teljesítménye megfelel a 2018. évi általános adatvédelmi rendeletnek (GDPR), amely szerint a nemmegfelelés akár 20 millió euróig vagy a megelőző éves jelentésben szereplő összes forgalom 4 százalékáig terjedő büntetéseket vonhat maga után. A GDPR egyik lényeges elve a személyes adatok védelmének felelőssége. Ebben az értelemben a globális vállalatok esetében nő a megfelelési kockázat. A szervezetek felelősek olyan keretrendszer kidolgozásáért, amely az üzleti kockázatok kezelésére szolgálnak, és előre meghatározzák azokat az intézkedéseket, amelyeket akkor kell megtenni, ha előfordulhat, hogy a számított kockázat esetleg veszélyezteti a vállalat teljesítményét.

A vállalatoknak korszerű adatelemzési eszközökbe kell beruházniuk ahhoz, hogy részletes, szakszerű és a lehető legmegbízhatóbb elemzésre tegyenek szert. Így nem lehet nehéz hozzájutni olyan tételek ellenőrzésével kapcsolatos részletes szakmai perspektívákhoz, mint például a beszerzések, az állóeszközök átértékelése, a pénzügyi veszteségek vagy az eszközök értékvesztése. A kínált előnyök ellenére az adatelemzést inkább szervezeti stratégiák kidolgozására használják; első körben vonakodtak az adatelemzés alkalmazásától az ellenőrzési küldetés tervezési szakaszában, kifejezetten az ügyfél megismerése érdekében. Mivel az adatforrások összetettsége és tartalma változó, az adatelemzés jelenti a mai könyvvizsgálók egyik elsődleges feladatát, ha a hagyományos ellenőrzési technikákat az új technológiákkal kívánják kombinálni.

A könyvvizsgálók támogatásért folyamodtak a könyvvizsgálói megbízás minőségének biztosítása és az ellenőrzött szervezet számára legmegfelelőbb üzleti megoldások meghatározása érdekében. A technológiák fejlődése tehát szorosabb kapcsolathoz és együttműködéshez vezetett az emberek és az AI-között, hozzájárulva az ML megjelenéséhez. Az előrejelzések megfogalmazásához szükséges kifinomult algoritmusok fejlesztése az ML teljesítményének alapja. Minél összetettebb a könyvvizsgálói megbízás és az alkalmazott technológia, annál nagyobb a nemmegfelelőségi vélemény megfogalmazásának kockázata. Ezért az ML elsajátítása, az adatok adatelemzés segítségével végzett elemzése, az AI alkalmazása, a blokkláncot alkalmazó számviteli nyilvántartások vizsgálata, a helyzetek és a technológiai előnyök azonosítása képezik a megfelelőségi véleményhez figyelembe vett szempontokat (Cristea, 2020).

A könyvvizsgáló cégek a tárolási platformokat adatelemzéshez használják, az alkalmazásokat és az AI-szoftvert pedig a szervezetről szóló 
információk optimalizálásához, nagy mennyiségü adat elemzéséhez, folyamatoptimalizáláshoz, számlák felismeréséhez és prediktív analitikához. Az új technológiák átvételében és felhasználásában a kihívást az jelenti, hogy a kognitív technológiákat integrálni kell a meglévő rendszerekbe (Deloitte, 2018). A kognitív technológiák összetett folyamatokat nem, de egyedi munkafeladatokat vagy a teljes folyamat (vagyis a pénzügyi ellenőrzési megbízás) összetevőit képesek teljesíteni.

Az emberek ellenállása az új technológiai változások befogadásával szemben valószínűleg abból ered, hogy nem rendelkeznek a manapság igazi kihívást jelentő munkafolyamatokhoz szükséges, kielégítő szintű tudással a kognitív technológiákról és munkában való felhasználásuk mikéntjéről (Deloitte, 2018). Az olyan vállalatok, mint például az Apple, a Google és az Amazon, amelyek az ismereteik és az általuk végzett munka terén vezető szerepet töltenek be, sikeresen vezették be az új technológiákat. Innovatív stratégiáik és intézkedéseik a modern korban, az AI és az ML világában jól teljesítenek. A feltörekvő technológiákat átvevő és az új gazdasági környezethez alkalmazkodó cégeknek a könyvvizsgálói szakma részére olyan „vezérlő fényként” kell megjelennie, ahonnan fejlett technológiai készségeket és megfelelő intézkedéseket nyerhetnek informatikai műveltségük gyarapítása érdekében.

\section{KUTATÁSI MÓDSZERTAN}

Tekintettel arra, hogy a pénzügyi ellenőrzési megbízásokat számos koordináta befolyásolja - így például gyors szoftverfrissítések, az ellenőrzött ügyféltípus, amely a tevékenységi területtől függően változik (állami, magán), az üzemeltetőtől függően változó jogalap, vagy akár az alkalmazott technológiák - a jelen cikkben arra törekszünk, hogy tisztázzuk az informatika pénzügyi ellenőrzési megbízásokra és a romániai könyvvizsgálói szakmára gyakorolt hatását. A kérdőíves felmérésben a könyvvizsgálókat az új technológiák fejlődésével kapcsolatban annak első hatásairól, alkalmazkodásukról és szakmai véleményükről kérdeztük.

A jelen cikk felméréssel végzett, kvalitatív empirikus kutatáson alapszik (Sandor 2013, 119. oldal). A kérdőívet bejegyzett román könyvvizsgálóknak továbbították, és 19 kérdést tartalmazott, feleletválasztós és mátrix típusú válaszokkal. A beérkezett válaszok elemzése a jelen cikk lényege, a cél a hivatásos román könyvvizsgálók véleményének meghatározása az informatika hatásaival kapcsolatban. A referencia a szakirodalomról szóló szakaszban bemutatott, aktuális technológiai változásokhoz kapcsolódik. A kérdőívet kizárólag azok a román könyvvizsgálók kapták meg, akiknek e-mail címe megtalálható az aspaas.gov.ro nyilvános elektronikus nyilvántartás „Bejegyzett könyvvizsgálók” részében. 4731 e-mail lett kiküldve, 103 válasz érkezett be, amelyekből egy választ el kellet távolítani, mivel a résztvevő nem tartozott a célcsoporthoz, így ez 102 elemzett választ eredményezett. Az „Informatika hatása a könyvvizsgálói megbízásokra” című felmérés 2019. december 15. és 2020. június 10. között zajlott, és a következő észlelt szervezeti és adminisztratív kérdésekkel foglalkozott:

(1) speciális szoftverek (pl. Ciel Audit and Revision, Gaudit, CaseWare, Acceler IT) használata a könyvvizsgálati tevékenység során;

2a szakmai tevékenység során használt szoftver sajátossága;

3a használt számítógépes programmal kapcsolatos első hatás megítélése;

4 a vállalat által használt technológia típusa;

5a könyvvizsgálók véleménye a big data, az adatelemzés, a mesterséges intelligencia és a blokklánc megjelenéséről és fejlődéséről;

6 mennyiben változtatta meg a technológia a könyvvizsgálói megbízás egyes szakaszait, illetve mennyiben lett annak része; 
(7) szakma jövője a technológiai hatás következtében. Általánosan elfogadott nézet, hogy ez a szakma egyre jobban fejlődik, a külső környezet egyre jobban megbecsüli, és a jelenlegi munkafeladatokat fokozatosan felváltják az új technológiák;

8 szakmai továbbképzés biztosítása az új technológiákkal való munkavégzésről a könyvvizsgálói megbízások jó teljesítményének elérése érdekében;

9a könyvvizsgálatról szóló továbbképzések jelenlegi szintje, figyelembe véve az informatika folyamatos fejlődését és forradalmát, valamint az érdekelt felek növekvő igényeit;

(10 a mai könyvvizsgáló alapvető tulajdonságai a szakma újra definiálásához;

Da Nemzetközi Könyvvizsgálati Standardok (ISA) megváltoztatásának lehetősége.

Az első kérdések a válaszadó szakmai tapasztalataira vonatkoztak, a következő információk alapján:

- a cégnél betöltött pozíció (például könyvvizsgáló, beosztott könyvvizsgáló, vezető könyvvizsgáló stb.),

- munkaterülete (például állami vagy magán szektor),

- a könyvvizsgálat terén szerzett tapasztalat (például 5 év alatt, 5-10 év, több mint 10 év),

- az ügyfelek nettó forgalma (például 50000 euró alatt, 50 000-100 000 euró, 100000 500000 euró, több mint 500000 euró).

A felmérés olyan speciális tanulmányokon alapult, amelyek elemzik az adatelemzési eszközök előnyeit, valamint az AI, a blokklánc és az RPA hatását a big data jelenséget illetően. Ezenkívül a felmérést alkotó kérdések részletes megfogalmazása azokat a szempontokat ragadta meg, amelyeket a szerző többéves munkatapasztalata és az egyetemi időszak alatt elemzett, ugyanis saját maga is könyvvizsgálók által ellenőrzött könyvelő volt.

A jelen cikk kiegészíti a korábbi speciális kutatást, amely azt vizsgálta, milyen mérték- ben vezették be könyvvizsgálói gyakorlatba az új technológiákat. A kapott válaszok száma elfogadható, tekintettel arra, hogy az erre irányuló korábbi munkák hasonló mintát mutattak be (Săcărin, Bunea és Gîrbină, 2013; Abou-El-Sood, 2015; Tarek, 2017; Rîndașu, 2017). A legtöbb válaszadó vezető könyvvizsgálói pozíciót tölt be (24,5 százalék), őket követik a partnerpozíciójú könyvvizsgálók (20,6 százalék), a senior könyvvizsgálók (16,7 százalék), belső ellenőrök (13,7 százalék) és más kategóriák (könyvvizsgáló, állami belső ellenőr, igazgatóhelyettes, pénzügyi, számviteli osztályvezető, tanácsadó, közgazdász) lásd 1. ábra.

A könyvvizsgálók szakmai tapasztalata változó. Az 5 év alatti szakmai tapasztalattal rendelkező válaszadók 11,8 százalékos arányban válaszoltak, az 5 és 10 év közötti válaszadók 17,6 százalékban, és a válaszadók többségének (70,6 százalék) több mint 10 éves tapasztalata volt. A felmérésben részt vevők fóleg a magánszférában (83,3 százalék), de néhányan az állami szférában is dolgoztak (16,7 százalék). Az ügyfelek nettó forgalma változó, a legtöbb könyvvizsgáló olyan ügyfeleknél dolgozott, akik több mint 500000 euró nettó forgalommal rendelkeztek (61,8 százalék).

\section{EREDMÉNYEK ÉS VITA}

A legtöbb válasz a könyvvizsgálatban tapasztalattal rendelkező válaszadókra vonatkozik, akik már megalapozott tudásra tettek szert, figyelembe véve a vállalatban betöltött pozíciójukat (vezető könyvvizsgáló), az 51 év körüli átlagéletkorukat, és a 10 évet meghaladó szakmai tapasztalatukat. A résztvevőktől megkérdeztük, hogy tevékenységük során használnak-e speciális szoftvereket, 62,7 százalékuk kijelentette, hogy a mindennapi munkában használ számítógépes programokat. Már tudjuk, hogy a számviteli és a könyvvizsgáló szoftverek hasznosságát széles körben elismerik a pénzügyi 


\section{ELLENŐRZÖTT ÜGYFELEK NETTÓ FORGALMA}

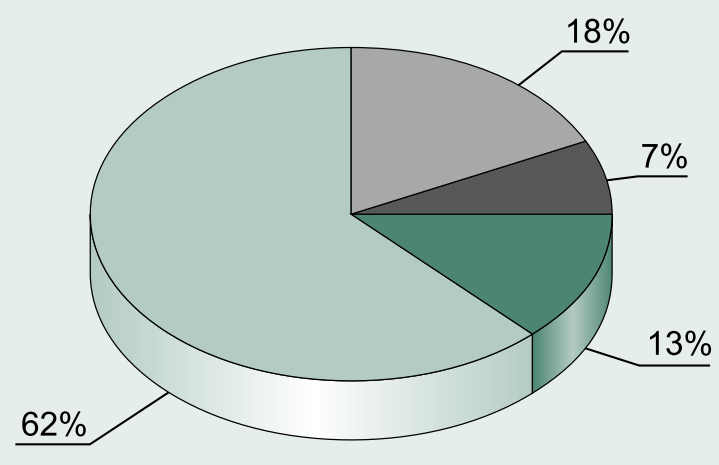

50000 euró alatt

50 000-100 000 euró

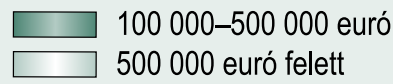

Forrás: a szerző saját feldolgozása, az összegyűjiött adatok alapján

ágazatban, ahol a könyvvizsgálói megbízások megfelelő lebonyolításához különféle lépéseket kell végrehajtani, például ellenőrzések, öszszefüggések, részletes adatvizsgálatok, valamint a tényszerű és a számszerü bizonyítékok öszszehasonlításához forrásként szolgáló számos konzultáció. A kérdőív a szakmai tevékenység során használt szoftverekre vonatkozóan másik kérdést is tartalmazott (lásd 2. ábra).

Felmérésünk eredményei szerint a $\mathrm{Ciel} \mathrm{Au}$ dit and Revision alkalmazást a román könyvvizsgálók 19,6 százaléka használja, a Gauditot 10,8 százalék alkalmazza, ezt követi a CaseWare (5,8 százalék) és az AccelerIT (2 százalék). 61,8 százalék egyéb szoftvereket említ a szakmai tevékenységre vonatkozóan, például Microsoft Excel, CAAT, BCOMM Audit Manager, IDEA ${ }^{\oplus}$ Data Analysis Software, B\&B, Pentana, AuditX, AURA (PwC specifikus könyvvizsgáló szoftver), SAGA a szám- vitel ellenőrzéséhez, SAP Audit Management, SIUI, SIPE, Sintact.ro vagy más, a vállalat által házon belül fejlesztett szoftver. A Ciel Audit and Revision programot Romániában széles körben használják az elérhető menü és az intuitív parancsok miatt, és megbízható informatikai támogatást jelentenek a könyvvizsgálói tevékenységekhez. A nagy könyvvizsgáló cégeknél az IDEA ${ }^{\oplus}$ adatelemző szoftver több mint népszerü, mivel különféle eszközöket tartalmaz az adatok leválogatására és a magas kockázatú összegek elemzésére. A könyvvizsgálók az „egyéb” lehetőséget választhatták, ha az előre definiált változatok nem voltak megfelelők.

Összevetve eredményeinket Caranica (2016) 2015-ös felmérésen alapuló tanulmányával, figyelembe vehetjük, hogy a román könyvvizsgálók következetesek és túlnyomórészt hűek maradtak a különféle alkalmazáso- 


\section{A KÖNYVVIZSGÁLÓI MEGBíZÁSOK SORÁN HASZNÁLT SZOFTVER}

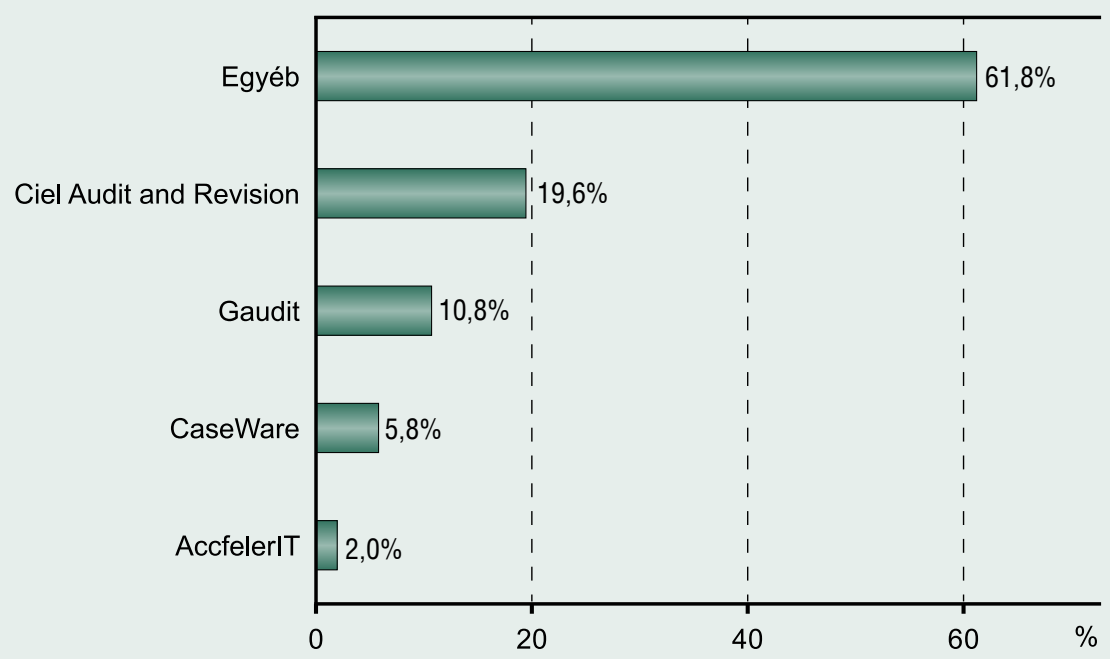

Forrás: a szerző saját feldolgozása, az összegyűjiött adatok alapján

kat (Microsoft Excel, Ciel Audit and Revision, CaseWare, Gaudit) illetően. A mi eredményeink azonban más szoftveralkalmazásokat is mutattak, figyelembe véve a 2015 és 2020 közötti technológiai fejleményeket. A technológia kezdeti hatását először nehéznek, majd idővel könnyebbnek ítélték meg. A válaszadók egy része alkalmazkodott az új technológiákhoz (37,3 százalék), mások úgy vélték, hogy a számítógépes programok könnyen használhatók és hozzáférhetők (33,3 százalék). A válaszadók 10,8 százaléknál a kezdet nehéz volt, ehhez segítségre volt szükségük. Mivel a legtöbb szervezet a pénzügyi-számviteli információk rögzítésén és feldolgozásán alapul, figyelembe véve a lenyűgöző technológiai fejlődést, manapság a vállalatok (még a kisvállalkozások is) speciális szoftvereket használnak annak érdekében, hogy valós idejű információkat nyújtsanak az ügyfelek és a befektetők számára.
A 3. ábra azt mutatja, hogy az adatelemzés a román könyvvizsgálók által leggyakrabban használt technológia (52,9 százalék), amely eredményt a big data jelenség határozta meg (21,6 százalék).

A részletes elemzést az adatelemzés segítségével hajtják végre, amely eszköz segíti a könyvvizsgálókat az ügyfelek adatainak jobb megértésében. Igenlő választ adtak az AI (5,9 százalék) és a blokklánc (3,9 százalék) esetében is. Az AI és a blokklánc két viszonylag új technológia Romániában, a könyvvizsgálói szakma érdeklődését felkeltették, és hamarosan teljes szintre lépnek. A blokklánc előnye a biztonsági tranzakciók könyvvizsgálatával jellemezhető, más szóval az egyszer létrehozott adatok később nem változtathatók meg. Az AI ahhoz a robotika által elvégezhető munkához kapcsolódik, amely jelenleg időigényes, és amelyet egyelőre a könyvvizsgálók végeznek. Intelli- 


\section{A TECHNOLÓGIA TÍPUSÁNAK ALAKULÁSA}

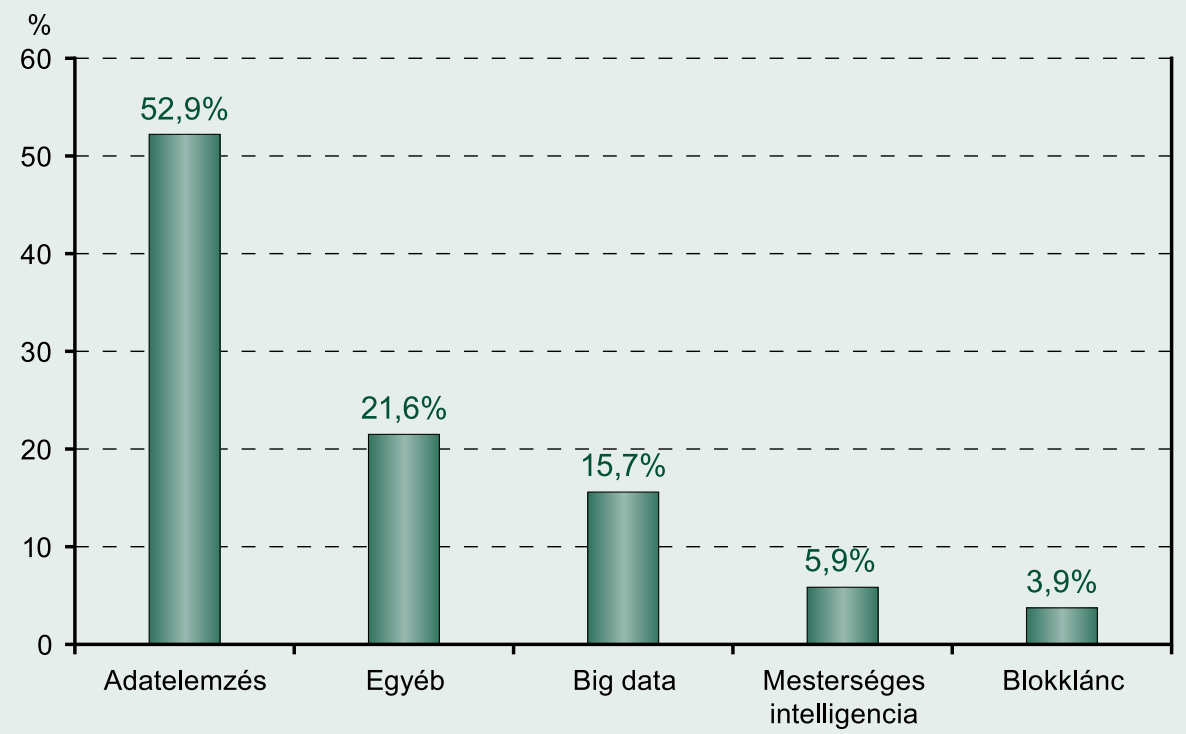

Forrás: a szerző saját feldolgozása, az összegyűjiött adatok alapján

gens modulok létrehozásával az AI kiválaszthatja azokat a tranzakciókat, amelyeket korábban potenciális csalási kockázatként észleltek, majd ezt követi a nem egyértelmű helyzetek elemzése és felderítése.

A válaszadók fennmaradó 21,6 százaléka más eszközöket alkalmazott vagy más munkamódszereket részesített előnyben. Ilyenek például adatautomatizálás és adatelemzés, Excel, dokumentumkezelő rendszer, VPN, házon belül fejlesztett szoftverek beépített modulokkal, tervezett szoftverek a szerződésekhez/projektekhez, a pénzügyi számviteli modulokban levő információk megszerzése (azaz kifizetések és nyugták, szállítók és vevők, hitelezők, bevételek és kiadások információi), kezelési programok és személyre szabott könyvelés, elektronikus könyvvizsgálati fájlok, adatbázisok társítása módszertanokhoz, automatizált kérdőívek, mintavételi szoftverek (3. ábra).
Az új információs technológiákat a megvalósítási költségek ellenére (különösen) a nagyvállalatok integrálták elsőként pénzügyi rendszereikbe, ugyanis ezáltal magas minőségü információk váltak elérhetővé. Ugyanakkor az adatelemzés, a mesterséges intelligencia és a blokklánc-funkciók használata a könyvvizsgálati nyomvonalat teszi láthatóvá, csökkenti az emberi adatbevitelt, a hibaarányt és a munkaterhelést. A feltörekvő technológiák alkalmazásával a könyvvizsgáló képes lenne például automatizálni az egy évnél régebbi hátralékos tranzakciók vagy a 100000 román lej összeget meghaladó szerződések kiszürését.

A válaszadók 55,9 százaléka úgy vélte, készen áll az új technológiák alkalmazására, 29,4 százalékuk az válaszolta, hogy nem volt teljesen felkészült erre, míg 14,7 százalékuk pozitív hozzáállását részletezte, és hogy nyitott volt továbbképzésekre és technológiai felké- 
szítésre. A válaszadóknak több információra van szüksége az elfogadáshoz, véleményük szerint ugyanis minden új dolog magyarázatot igényel. Sajátos esetként a válaszok elemzése alapján egyes könyvvizsgálók nem érzik magukat késznek arra, hogy robotokkal dolgozzanak. Az RPA viszonylag új téma a könyvvizsgálói szakmában, és csak a közelmúltban tört előre a pénzügyi ellenőrzés terén. Az RPA teljes körü megvalósításával a könyvvizsgáló már nem lesz felelős az ellenőrzési folyamatot kiegészítő, ismétlődő munkaterhelésekért (a thickening és a bashing), mert a szoftver vagy a robot felel majd azokért az ismétlődo” műveletekért, amelyek egy bizonyos rutinfolyamatot követnek, és amelyek esetében a legtöbb helyzet már ismert és mintákba beágyazva rendelkezésre áll az RPA-elemzéshez. Egy másik válaszadó olyan folyamatosan fejlődő területként fogalmazta meg a könyvvizsgálatot, amelyre soha nem lehet senki sem teljesen felkészült, mivel könyvvizsgálóként feladata az új technológiai készségek folyamatos elsajátítása.

A technológia jelentősen megváltoztatta a munkavégzés módját és magát a könyvvizsgálói szakmát is (74,5 százalék). Korábban a pénzügyi információk ellenőrzése rendkívül időigényes volt, de jelenleg lehetőség van a házon belül fejlesztett szoftverek és adatelemzési eszközök segítségével egyszerűen és gyorsan elemzéseket végezni. A válaszadók 14,7 százaléka vélekedett úgy, hogy a technológia jelentéktelen mértékben változtatja meg a könyvvizsgálói megbízás folyamatát. Ezt olyan könyvvizsgálók képviselik, akik korábbi válaszukban a változásokkal szembeni ellenállásukról nyilatkoztak, valamint arról, hogy könyvvizsgálati ellenőrzéseket nem az új, hanem a régi ellenőrzési módszerek alapján végzik. A könyvvizsgálók ezen csoportját (vagyis a változásokkal szemben ellenállókat) konkrétabban elemezve az átlagéletkor 51 év volt, és korábban kijelentették, hogy nem érzik kész- nek magukat a feltörekvő technológiákra és a velük való munkára.

4,9 százalék úgy vélte, hogy - figyelembe véve a gazdaság jelenlegi felgyorsulását a technológia teljesen megváltoztatja majd a folyamat végrehajtását. Rövid időközönként akár tucatnyi szoftverfrissítést is tervezhetnek és vezethetnek be, így a könyvvizsgálói megbízások korábban hosszabb ideig, hetekig vagy hónapokig tartó szakaszait végezhetik el. Az ellenőrzött pénzügyi kimutatásokról stratégiai elemzések készülhetnek a szoftveres eredmények után, ami hatékonyabb, mint a kézi munka. Nem lenne meglepő, ha a technológia a jövőben (teljesen) megváltoztatná a könyvvizsgálói megbízás folyamatát, a legkisebb részletektől kezdve a folyamat véglegesítéséig, vagyis az a könyvvizsgálati jelentési folyamat befejezése utáni továbbítást is automatizálnák.

A könyvvizsgálói szakma jövőjét pozitív módon értékelik, abban az értelemben, hogy a technológia segíti a könyvvizsgálókat a könyvvizsgálói megbízásokban (44,1 százalék), ami a feltörekvő technológiák hatásának tudható be (45,1 százalék). A válaszadók nagyon kis százaléka érzékeli bizonytalannak a szakma jövőjét (7,8 százalék). Ennek oka, hogy Románia számára ezt a magas technológiai szintet nehéz elérni. Az informatikai eszközök perspektívája a gazdaságban és a társadalomban alacsony, ezért a digitális technológia és a digitális közszolgáltatások integrációja nem halad megfelelö ütemben.

A román könyvvizsgálók folyamatos képzését biztosítja, hogy továbbképzéseken (CAFR) vesznek részt (40,2 százalék), dokumentálják (15,7 százalék) és tesztelik az új big data technológiákat, mint például az AI-t, az adatelemzést és blokkláncot (13,7 százalék), valamint egyéb továbbképzéseken vesznek részt $(13,7$ százalék). Más válaszadók említést tettek az új szabályzatok, gyakorlatok és munkamódszerek integrációjáról, amit az új technológiák tesztelése és alkalmazása követett. Jelenleg a tovább- 
képzési programok továbbra is nagyvállalatoknál zajlanak. A multinacionális cégek olyan AI-programokat valósítanak meg és fejlesztenek, amelyek a pénzügyi adatok mélyebb megértése révén előnyöket jelentenek a könyvvizsgálati eljárás és a minőség szintjén egyaránt.

Romániában a jelenlegi képzési szint átlagos (68,6 százalék), más válaszadók szerint alacsony (19,6 százalék). Románia helyzete átlagosnak mondható a technológiai trendek változásai tekintetében, figyelembe véve az elvégzett felmérés eredményeit és a technológiai fejlettség jelenlegi romániai állapotát. A válaszadók mindössze 10,8 százaléka támogatta az emelt szintű képzést. Még ha az új technológiákkal való munka nem is nagyon fejlett, a válaszadók azt állították, hogy nagyobb elemzési és előrejelzési képességet (51 százalék), valamint módszertani változásokat észleltek $(22,5$ százalék). A könyvvizsgáló profiljában bekövetkezett változást a válaszadók ennek tulajdonították (16,7 százalék), az előrejelzéseket tartalmazó adatelemzési fókusszal együtt (5,9 százalék). A válaszadók mindössze 2 százaléka vélte úgy, hogy az érzelmi intelligencia fejlesztése része lesz a változásnak.

Az biztos, hogy a könyvvizsgálói szakma egyre inkább tökéletesedik. A válaszadók 51 százaléka értett egyet ezzel az állítással, valamint azzal, hogy a jelenlegi munkaterhelést fokozatosan új technológiák váltják fel $(32,4$ százalék). Úgy vélik, hogy a jövőben a könyvvizsgálói szakmát nagyobbra becsüli a külső környezet (15,7 százalék), mivel a könyvvizsgálói megbízások minősége jelentősen javulni fog. Azaz, a megbecsülés mértéke megfelel majd az előrehaladásnak, e szakma hasznosságát jobban elismerik majd.

A jelenlegi könyvvizsgálói készségek közül a szakmai szkepticizmust tartották a legfontosabb erénynek ( 56,9 százalék). A megkérdezettek 20,6 százaléka úgy vélte, hogy a versenykörnyezet megértése elengedhetetlen, emellett az érzelmi intelligencia fejlesztése $(8,8$ száza- lék), valamint az ügyfelek iránti empátia és a vállalati kutatások is fontosak. A válaszadók úgy ítélték meg, hogy több mint helyénvaló, hogy tudásukat informatikai ellenőrzéssel ötvözzék, mivel a szabályozások egyre bonyolultabbá válnak.

A Nemzetközi Könyvvizsgálati Standardok módosításának lehetőségét illetően a válaszadók 71,6 százaléka gondolta úgy, hogy az ISA módosulni fog, 19,6 százalékuknak nincs kifejezetten véleménye a témáról, míg 5,9 százalékuk amellett tartott ki, hogy nem kell változtatás. 2,9 százalék elismerte, hogy az ISA-t minden bizonnyal megreformálja majd az Etikai Kódex. Mint minden üzleti folyamat, a könyvvizsgálat is tökéletesíthető, mivel az Etikai Kódexnek tartalmaznia kell az AI megvalósításával kapcsolatos eseteket is. Végül a könyvvizsgálat jobb funkcionalitása érdekében az informatika kulcsfontosságú szerepet játszik az előrelépés biztosításában (57,8 százalék). Az informatika segíti a könyvvizsgálói szakmát abban, hogy „barátságosan” fogadja az új technológiák megjelenését, ami előretekintő szemléletmódot mutat, és fontos átmenetet jelent az ágazat fejlődésében (33,3 százalék). A válaszadók 5,9 százaléka elismerte, hogy az információtechnológia bevezetésével az ERP-rendszerek hozzájárulnak a vállalkozás jobb irányításához, valamint az elemzések és az üzleti előrejelzések javításához.

A román könyvvizsgálók 5,8 százaléka alkalmazta már a mesterséges intelligenciát, a jelen tanulmány esetében erre a kérdésre a 103 válaszadó közül csak 6-tól érkezett igenlő válasz. Ez az eredmény annak tudható be, hogy nem ismerik vagy nem ismerik fel e technológia „erejét”, amely lehetővé teszi a vállalatok számára, hogy felhasználják a rendelkezésre álló adatok mérhetetlen mennyiségét (big data), és ezáltal jobban megismerjék azokat a piacokat és tevékenységi szegmenseket, ahol az ellenőrzött társaság működik. Ma már az adatfeldolgozási „eljárás” részét képező CAAT- 
okkal együtt az AI megjelenése lehetővé tenné az adatelemzési folyamatokban alkalmazható kapcsolódó adatforrások és modellek összegyüjtését és értékelését. Az AI ezt ráadásul sokkal gyorsabban teszi, mint amire a múltban számítani lehetett.

Példaként említhetjük a bevételelszámolás példáját, amelyet komplex folyamatnak tartanak, tekintve a vállalatok és az általuk nyújtott szolgáltatások közötti kapcsolatokat és az információáramlást, amely biztosítja az üzleti folyamatok végrehajtását. Más szóval e tranzakciók bonyolultsága megnehezítheti a könyvvizsgálati folyamatot, és ez kezelhetetlen feladatokat eredményezhet, ami nagy munkaterheléssel járhat. A könyvvizsgáló ilyen esetben hagyományosan mintavételezést használna, és megvizsgálná az alátámasztó dokumentumok forrását, ellenőrizné a tranzakciók elszámolásának módját és a bevételelszámolási módszert.

\section{KÖVETKEZTETÉSEK}

A jelen cikk részletesen bemutatta, milyen hatással van az informatika az auditálási ágazatra. Figyelemreméltó előrehaladás történt a munka elvégzésének módjában, az ellenőrzési módszerek alkalmazásában és a csalások valószínűségének kivizsgálásában. A negyedik ipari forradalom során az adatelemzési eszközök, az AI megjelenése, a robotizált folyamatautomatizálás kifejlesztése és a blokkláncbiztonsági tranzakciók új, big data korszakhoz vezetnek a könyvvizsgálatban is. A felmérés eredményei azt mutatják, hogy szakmai szinten ismeretes, hogy a munkában a szakmai készségek további fejlesztésére van szükség, és (teljesen) felismerik a technológia hatását.

A könyvvizsgálóknak meg kell tanulniuk, hogy a könyvvizsgálói megbízás különböző fázisait hogyan lehet automatizálni. A speciális képzés vagy technikai tapasztalat hiánya megakadályozhatja az új, automatikus munka- rendszerekhez való alkalmazkodást. Az új technológiák nem kellő ismerete a munkában alacsony elégedettségi és termelékenységi szinthez vezethet, emiatt új készségeket kell kialakítani, felhasználni e szakma műveléséhez. Az új technológiai fejlesztések terjesztése érdekében, és hogy azok használata szokásossá váljon a cégeknél, fontolóra kell venni a gyakori továbbképzést, más szóval az elmélet megértését a gyakorlat érdekében. A „szokásossá váljon” kifejezésen azt értjük, hogy az új technológiáknak általánossá kell válniuk a könyvvizsgálói megbízásokban, azaz a könyvvizsgálónak automatizált technikával, az adatelemzési és AIeszközök könnyű elérésével ellenőrizni kell az információkat (a rendszeren keresztül). A válaszadók úgy vélték, hogy az új technológiákkal kapcsolatos speciális továbbképzés és dokumentáció jelentősen hozzájárulna ahhoz, hogy a könyvvizsgálói megbízások során a technológia használatát „szokásosnak” tekintsék.

A leendő és a jelenlegi könyvvizsgálók egyaránt figyelembe vehetik az üzleti igényekre adott megfelelő válasz fontosságát. A közelmúltban a nemzetközi szakmai szervezetek felhívták a figyelmet az új, modern technológiájú könyvvizsgálati rendszerekről szerzett ismeretek elsajátítására. A jövő technológiáiról szóló aktuális információk elérése értékes támogatást nyújthat a feltörekvő technológiák megértéséhez, ezáltal pedig az ellenőrzött adatok szigorú ellenőrzéséhez, valamint a nemmegfelelőség kockázatának csökkentéséhez is. Az elvégzett elemzéssel bizonyítékot nyújtottunk arra, hogy Romániában nem definiálták teljesen, mi az a tudásterület, amelyet jelentősen fejleszteni kellene. A szerző véleménye szerint a szakmai testületeknek fontolóra kellene venniük, hogy újonnan és egyértelműen határozzák meg a könyvvizsgálók kompetenciáit annak érdekében, hogy jelentősen csökkentsék a jelen cikkben közölt százalékos tudáshiányt.

A könyvvizsgáló az, aki meghozza a végső döntéseket, és biztosítja a szervezet számára a 
megoldást a szervezeti stratégia felülvizsgálatához, a hatékonyabb kontrollok végrehajtásához és az ismétlődő operatív folyamatok ütemezéséhez a jobb jövőbeli értékelés érdekében. Mivel végül a könyvvizsgáló a könyvvizsgálati jelentésért felelős szakember, szakmai szkepticizmusának felhasználása mellett a technológia véleményünk szerint támogatást jelent számára, és kiegészíti ellenőrzési tevékenységét. A válaszadók többnyire nincsenek tisztában a Nemzetközi Könyvvizsgálati Standard módosításaival, és vannak ismeretlen részletekre vonatkozó kérdések. A felmérés eredménye alapján a résztvevők úgy vélik, hogy az ISA-t valóban módosítani kell a könyvvizsgálók Etikai Kódexével való jobb összehangolás érdekében.

Kétségtelen, hogy a feltörekvő technológiák jelentősen pozitívan hatnak a könyvvizsgálói szakmára, a környezetre, és - ami a legfontosabb - a mindennapi folyamatok hatékonyságára és optimalizálására. A könyvvizsgálók tisztában vannak azzal, hogy szükség van az újrakezdésre, vagyis életképes alternatívák elfogadására, az adatelemzés, a blokklánc, az RPA, a gépi tanulás terén meglévő ismereteik bővítésére annak érdekében, hogy a meglévő eljárásokat újakkal frissítsék. Jelen cikk a CAAT-okat is támogatja, mivel a CAAT-ok lehetőséget nyújtanak a könyvvizsgálóknak az adatfeldolgozás és a folyamatos monitorozás javítására. A blokklánc és az AI auditszoftverek által előállított teljesítésigazolás alapvető lendületet jelent a pénzügyi szektor számára, még akkor is, ha a könyvvizsgálók és a könyvelők még nem ismerik az új technológiákat és azok felhasználásának módját. Ez mindkét szakmában döntő fontosságú volna ahhoz, hogy a szakemberek naprakészek maradjanak és sikeresek legyenek.

\section{IRODALOM}

Aвou-El-Sood, H., Котв, A., Allam, A. (2015). Exploring Auditors' Perceptions of the Usage and Importance of Audit Information Technology. [Könyvvizsgálók meglátásainak feltárása a könyvvizsgálati információtechnológia használatáról és fontosságáról.] International Journal of Auditing, 19(3), pp. 252-266

Ahmad, A., SaAd, M., Bassiouni, M. et al. (2018). Towards Blockchain-driven, Secure and Transparent Audit Logs. In Proceedings of the 15th EAI International Conference on Mobile and Ubiquitous Systems: Computing, Networking and Services. [A blokklánc-vezérelt, biztonságos és átlátható ellenőrzési naplók felé. A „Mobil és mindenütt jelenlévő rendszerekről” szóló, 15. EAI Nemzetközi Konferencia eljárásrendjében: számítástechnika, hálózatépítés és szolgáltatások.] pp. 443-448
Anders, S. B. (2019). Audit Resources. [Ellenörzési erőforrások.] The CPA Journal, 89(2), pp. 70-71

Brown-Liburd, H., Vasarhelyi, M. A. (2015). Big Data and Audit Evidence. [Big Data és könyvvizsgálati bizonyítékok.] Journal of Emerging Technologies in Accounting,12(1), pp. 1-16

Byrnes, P. E., Al-Awadhi, A., Gullvist, B. et al. (2018). Evolution of Auditing: From the Traditional Approach to the Future Audit. In Chan, D.Y., Chiu, V., Vasarhelyi, M.A. (Eds.), Continuous Auditing (Rutgers Studies in Accounting Analytics). Emerald Publishing Limited, London, [Az auditálás alakulása: A hagyományos megközelítéstől a jövő könyvvizsgálatáig, Folyamatos könyvvizsgálat. (Rutgers tanulmányok a számviteli analitikáról.)] pp. 285-297 
Caranica, C. (2016). Cercetari Privind Utilizarea Instrumentelor Informatice în Auditul Financiar. [Kutatás az informatikai eszközök használatáról a pénzügyi auditálás során] Audit Financiar, 14(1), pp. 32-39

Castka, P., Searcy, C., Mohr, J. (2020). Technology-enhanced Auditing: Improving Veracity and Timeliness in Social and Environmental Audits of Supply Chains. [Technológia által továbbfejlesztett könyvvizsgálat: A hitelesség és az időszerűség javítása az ellátási láncok társadalmi és környezeti könyvvizsgálatában.] Journal of Cleaner Production, 258,120773

Clark, A. (2018). The Machine Learning Audit - CRISP-DM Framework. [A gépi tanulás könyvvizsgálata - CRISP-DM-keretrendszer.] ISACA Journal, 1

Cohen, M., Rozario, A. (2019). Exploring the Use of Robotic Process Automation (RPA) in Substantive Audit Procedures. [A robotizált folyamatautomatizálás (RPA) használatának feltárása a lényeges könyvvizsgálati eljárásokban.] The CPA Journal, 89(7),pp. 49-53

Cristea, L. M. (2020). Innovations in Financial Audit Based on Emerging Technologies. [Innovációk a pénzügyi ellenőrzésben az újonnan kialakuló technológiák alapján.] Audit Financiar, XVIII, 3(159) pp. 513-531,

https://doi.org/10.20869/AUDITF/2020/159/016

Gartner (2019). Why Audit Leaders Need to Adopt RPA. Retrieved July 3, 2020, from https:// www.gartner.com/smarterwithgartner/why-auditleaders-need-to-adopt-rpa/ [Miért kell az auditálási vezetőknek elfogadniuk az RPA-t.] A linkről letöltve: 2020. július 3 .

Gepp, A., Linnenluecke, M. K., O’Neill, T. J. et al. (2018). Big Data Techniques in Auditing Research and Practice: Current Trends and Future
Opportunities. [Big data technikák a könyvvizsgálati kutatásban és gyakorlatban: Aktuális trendek és jövőbeli lehetőségek.] Journal of Accounting Literature, 40, pp. 102-115

Gray, G. L., Debreceny, R. S. (2014). A Taxonomy to Guide Research on the Application of Data Mining to Fraud Detection in Financial Statement Audits. $[\mathrm{Az}$ „adatbányászat alkalmazása a csalások felderítésére a pénzügyi kimutatások könyvvizsgálatánál” témájú kutatásokhoz útmutatóként szolgáló rendszertan.] International Journal of Accounting Information Systems, 15(4), pp. 357-380

Griffin, P. A., Wright, A. M. (2015). Commentaries on Big Data's Importance for Accounting and Auditing. [Kommentárok a „Big Data jelentősége a számvitelben és a könyvvizsgálatban” témához. Számviteli horizontok.] Accounting Horizons, 29(2), pp. 377-379

Laureano, R. M., Pedrosa, I. (2016). Computer-assisted Audit Tools in Verification Tasks: Implementation in Microsoft Excel and in CaseWare IDEA. In 2016 11th Iberian Conference on Information Systems and Technologies (CISTI), [Számítógéppel támogatott könyvvizsgálói eszközök az ellenőrzési feladatokban: Megvalósítás a Microsoft Excelben és a CaseWare IDEA-ban.] 2016-ban a 11. Ibériai Információs Rendszerek és Technológiák Konferencián (CISTI), pp. 1-7

Leite, J., Silva, A. (2018). Computing Prediction Intervals with CAATTs: Implementation in CaseWare IDEA and Complemented in $\mathrm{R}$ project Software. In 2018 13th Iberian Conference on Information Systems and Technologies (CISTI), [Az előrejelzési intervallumok kiszámítása CAATTokkal: megvalósítás a CaseWare IDEA-ban és kiegészítve az R-projekt szoftverben.] 2018-ban a 13. Ibériai Információs Rendszerek és Technológiák Konferencián (CISTI), pp. 1-6 
Moffitt, K. C., Rozario, A. M., Vasarhelyi, M. A. (2018). Robotic Process Automation for Auditing. [Robotizált folyamatautomatizálás a könyvvizsgálathoz.] Journal of Emerging Technologies in Accounting, 15(1), pp. 1-10

Rîndașu, S. M. (2017). Emerging Information Technologies in Accounting and Related Security Risks-what is the Impact on the Romanian Accounting Profession. [Feltörekvő információs technológiák a számvitelben és a kapcsolódó biztonsági kockázatokban - mi a hatása a román könyvelői szakmára.] Journal of Accounting and Management Information Systems, 16(4), pp. 581-609

Rozario, A. M., Thomas, C. (2019). Reengineering the Audit with Blockchain and Smart Contracts. [Könyvvizsgálat újratervezése blokklánccal és intelligens szerződésekkel.] Journal of Emerging Technologies in Accounting, 16(1), pp. 21-35

SăCĂRIN, M., BuneA, Ş., Gîrbină, M. (2013): Perceptions of Accounting Professionals on IFRS Application at the Individual Financial Statements: Evidence from Romania. [A könyvelési szakemberek meglátásai az IFRS alkalmazásával kapcsolatban az egyéni pénzügyi kimutatásokban: Bizonyíték Romániából. Számviteli és vezetési információs rendszerek.] Accounting and Management Information Systems, 12(3), pp. 405-423

Sutton, A., Samavi, R. (2017). Blockchain Enabled Privacy Audit Logs. In International Semantic Web Conference. [Blokklánc-engedélyezett adatvédelmi naplók.] Nemzetközi szemantikai webkonferencia, pp. 645-660

ŞAndor, S. D. (2013). Metode și tehnici de cercetare în științele sociale. Tritonic

TareK, M., Mohamed, E. K., Hussain, M. M. et al. (2017). The Implication of Information Technology on the Audit Profession in Developing
Country. [Az informatika következményei a könyvvizsgáló szakmára nézve a fejlődő országokban.] International Journal of Accounting \& Information $\mathrm{Ma}$ nagement

Tiwari, A., Hooda, N. (2018). Machine Learning Framework for Audit Fraud Data Prediction. [A gépi tanulás keretrendszere az adatcsalás előrejelzéséhez a könyvvizsgálatban.] Universal Review, 7(6), pp. 164-167

VAsarhelyi M., (2020). Smart Audit: the Digital Transformation of Audit. In BIG DATA and Digital Audit. 1, [Intelligens könyvvizsgálat: a könyvvizsgálat digitális átalakulása. Big data és digitális könyvvizsgálat.] Journal, (1) pp. 27-35, letöltve 2020. november 30-án a következő linkről: https://www.eca.europa.eu/Lists/ECADocu ments/JOURNAL 20_01/JOURNAL 20_ 01.pdf

William Jr, M., Glover, S., Prawitt, D. (2016). Auditing and Assurance Services: A Systematic Approach. McGraw-Hill Education. [Könyvvizsgálati és bizonyosságnyújtási szolgáltatások: Szisztematikus megközelítés.]

Zhang, J., Yang, X., Appelbaum, D. (2015). Toward Effective Big Data Analysis in Continuous Auditing. [A hatékony big data elemzés felé a folyamatos auditálásban.] Accounting Horizons, 29(2), pp. 469-476

CPA (2017). Blockchain Technology and its Potential Impact on the Audit and Assurance Profession. Chartered Professional Accountants Canada and the American Institute of CPAs. [Blokklánc-technológia és annak lehetséges hatása a könyvvizsgálói és a bizonyosságnyújtási szakmára. Kanadai Mérlegképes Könyvelők és Amerikai CPA-k Intézete.]

Deloitte (2018). Cognitive Technologies, Retrieved. July 1 2020, from https://www2.deloitte. 
com/us/en/insights/focus/cognitive-technologies/ technical-primer.html [Kognitív technológiák.]

A linkről letöltve: 2020. július 1
KPMG (2017). Harnessing the Power of Cognitive Technology to Transform the Audit. KPMG International. [A kognitív technológia erejének kiaknázása a könyvvizsgálat átalakításához.] 